\title{
Chemical Warfare.
}

R. HERBERT LEVINSTEIN, in a lecture delivered on Feb. 3 before the London section of the Society of Chemical Industry, courageously examined the position of chemical disarmament and chemical warfare in relation to the ideals and foundations of future peace and to the stern realities of the dangers of conflict. Whilst it is probably true that man is by nature a peaceable creature, and hence amenable to the settlement of domestic disputes peaceably under compulsion of law, the extension of the same principle to international disputes, however devoutly to be sought, is not so simple as may appear. The necessities of life are provided for the individual who falls in the social struggle but not for the nation which succumbs in society organised on competitive principles, and the possibility of defensive resort to arms remains in the background of international agreements. Hence with the present organisation of society the possibility of fighting is never remote, and Dr. Irevinstein's first plea was for the strengthening of the efforts of the League of Nations in making wars on a large scale less probable.

In international disputes, arms are the last resort; other means of persuasion are equally available, and not the least powerful is the possession of a powerful chemical industry. Restriction of naval armaments, largely an economic measure, by making war cheaper tends in a sense to make it easier, and in Dr. Levinstein's opinion increases the importance of the chemical arm. Examination of the text of the agreements relating to the prohibition of chemical warfare leads to the conclusion that the prohibition is largely ineffective. He finds, for example, no prohibition of the use of screening smokes ; yet it may be argued that such smokes as that of chlorosulphonic acid are in concentrated form deleterious to the human organism and are therefore forbidden. Justification of the use of a smoke can be based on the grounds that its toxic properties are accidental, as indeed are those of the fumes from high explosive shells. Tear gases, used in the United States for the protection of banks and safe deposits and for dealing with riots and civil disturbances, may be classed as non-asphyxiating and non-poisonous, since in low concentration they affect the eyes alone.

Chemical warfare has not, said Dr. Levinstein, been justly condemned by the general opunion of the world ; condemnation lies against its use by the Germans in
1915 in violation of the spirit, if not of the letter, of the Hague Convention, and because it was used against unprotected troops. He asked why preference should be shown for the use of high explosives with their ghastly effects ; there is, unfortunately, no prohibition against the dropping of high explosive shells or incendiary bombs from hostile aircraft at dead of night on crowded cities.

The object of war is not to destroy human life, but to break down the opponent's will to resist. Gas, Dr. Levinstein claimed, maims or kills a far smaller proportion of those whom it puts out of action than does any other weapon used in the recent War ; thus in proportion to the military results it causes far less human suffering, and, in addition, less of the wasteful destruction of the work of man. Dr. Levinstein quoted statistics showing that of the casualties caused by gas only $2-3$ per cent died and few-about 0.5 per cent-were permanently injured, whilst of casualties resulting from all other forms of warfare 25-33 per cent died, and of the survivors 2-5 per cent were maimed, blinded, or disfigured for life. He did not suggest that gas warfare is anything but dreadful, but he argued that it is both less dreadful and of greater military value than the older forms of warfare. It causes inconvenience, holds the element of surprise, permits economy of force, and is equally serviceable in attack and defence.

In Dr. Levinstein's opinion it is an elementary act of prudence for a nation situated as is Britain to see that research for chemical warfare purposes should continue to be a subject for special study, and that funds for that purpose should not be reduced below the safety point. Guns and shells can be restricted, and in any case take long to prepare, but gas can be projected from quickly improvised containers ; limitation of armaments as proposed may therefore greatly increase the military importance of the chemical weapon, and prudence dictates contact in peace time between military authorities and the chemical industries.

If a purely general observation supplementing $\mathrm{Dr}$. Levinstein's remarks may be offered, it is simply that modern warfare in all its forms is increasingly based on chemical knowledge, and that if chemical research can make warfare even a little less probable and Iess hideous, its potentialities in that direction deserve the attentive interest and unbiassed support of all right-minded men and women.

\section{Variations in the Skeletal Structure of the Pig.}

$\mathrm{H}^{\mathrm{s}}$ AVING observed marked variations in the lengths of exhibition carcases of swine used for bacon curing, Prof. A. M. Shaw, of the University of Saskatchewan, suspected that the difference might be due to variations in the numbers of ribs. He accordingly counted them and found that, of nine carcases exhibited, two possessed 16 pairs of fully developed ribs, four possessed 15 pairs, while the remaining three carcases possessed 14 pairs of fully developed ribs each.

Reference to standard works on veterinary anatomy was made. Sisson states: "The ribs number fourteen or fifteen pairs. The fifteenth rib when present may be fully developed and its cartilage enter into the formation of the costal arch; but in most cases it is only about an inch $(2-3 \mathrm{~cm}$.) in length." The vertebral formula given by Sisson is : $C 7, T$ 14-15, $L$ 6-7, $S 4, C y 20-23$. He also states that "the occurrence of fifteen thoracic vertebræ is quite common and the existence of sixteen or even seventeen has been re- corded. Reduction to thirteen is very rare." Various model pig skeletons examined by Shaw all possessed what was apparently considered to be the normal number, namely, 14 pairs.

Prof. Shaw has had careful counts made in Canada, the United States, Great Britain, and Denmark, and has now published the figures for 3957 animals, representing several breeds, grades, and erosses (Scient. Agric., 10, 1; September 1929). When summarised they show the following results: 13 pairs of ribs, 20 pigs ; 14 pairs, 1574 pigs ; 15 pairs, 1829 pigs; 16 pairs, 310 pigs; 17 pairs, 7 pigs. The remainder showed uneven pairs or floaters. More than 4.00 vertebral columns were scraped and cleaned for identification, varying in number of ribs from 13 to 17 . The counts showed that cervical (7) and sacral (4) remained constant, thoracic varied according to the number of ribs, while the lumbar variation is from 6 to 7 , except in two cases, where there were only 5 present. The true ribs were always attached to

$$
\text { No. } 3146 \text {, Vox. 125] }
$$


thoracic vertebræ and the increase in lumbar vertebræ were associated with the smaller number of ribs present and vice versa. There appeared to be no relationship between sex and the number of ribs. Very interesting observations were made in regard to litter mates in that " no normal litters were found where all pigs possessed the same rib number".

In addition to the scientific value of these observations, the economic aspect of rib variation in pigs is of considerable importance from the point of view of bacon, since the increased length of the carcase is mainly in that region usually regarded as furnishing the prime cuts. The awards in various competitions supports this, even though the judges apparently had no thought of rib count. Moreover, in a private communication Prof. Shaw states "there seems to be ample evidence that the animals with fifteen and sixteen pairs of ribs are decidedly superior from the standpoint of rate of growth and economy of gains to those possessing thirteen or fourteen pairs".

\section{The Sugar Industry.}

THE world's sugar industry was the subject of

the Streatfeild Memorial Lecture delivered at the Institute of Chemistry by Mr. Lewis Eynon, on Nov. 22,1929 , and recently published. Sugar cane, which until about 130 years ago, was the only source of sugar, was known before the Christian era, and is supposed to have originated in India. Arabs and Egyptians, however, were the pioneers in the art of crystallising sugar many centuries later. Sugar appears to have been first imported into England from the Mediterranean countries in the fourteenth century, and the art of refining introduced during the reign of Henry VIII. During the seventeenth and eighteenth centuries, however, the bulk of the world's sugar was derived from America and the West Indies, where abundant slave labour and good growing conditions particularly favoured the industry.

Attempts to produce sugar from sources other than cane were first made in Europe during the Napoleonic Wars, when the possibilities of utilising grapes and beetroot were investigated, but without much success in the former case. With the exception of France, where the industry obtained government support, it was short-lived, and did not become general in Europe until 1860.

Despite the development of the beet sugar industry, the importation of cane sugar into Europe continued to increase for some time, and although during the latter part of the nineteenth century the cane sugar industry suffered temporarily from severe competition, the markets gradually adjusted themselves, and in 1901-2 cane and beet each contributed about 50 per cent of the world's production of sugar. Sugar beet growing was first attempted in England seventy years ago ; but the industry developed but little until the raising of the subsidy in 1925 .

Besides the cane and beet sugar industries, the production of glucose from starch, first discovered in 1811, is an important manufacture. Improved methods, the discovery of new sources of sugar, and the extension of the industry into temperate climates have enormously increased the world's supply of sugar.

Although sugar, at one time a luxury, has now become an important article of food, human consumption is not likely to increase at the same rate as the supply, and it seems that a new use for sugar must be found, or further growth of the industry will be impossible. The production of power alcohol from sugar seems to be the solution of the problem, and it would also provide a useful substitute for petrol before the world's store of this is exhausted. The future prosperity of the sugar industry would thus seem assured.

\section{Bacterial Infection in Fish.}

TN the issue of Narure dated Dec. 29, 1928 (p. 1012), there appeared a short notice of recent work on furunculosis in Salmonidæ by Dr. Clayton and Miss I. J. Williamson working independently. Since then, Miss Williamson has continued and extended her studies on this disease, the results of which are embodied in two papers recently published by the Fishery Board for Scotland. The external signs and visceral changes in furunculosis she finds to be variable, and there may be no external symptoms, isolation of the bacillus (B. salmonicidus) often being the only method of diagnosis. 1 A notable and very important feature of the disease is that apparently healthy fish can act as 'carriers' of the bacillus, but no means has as yet been evolved for distinguishing such 'carriers' from uninfected fish while still alive. Rainbow trout can also be attacked by the disease, and act as 'carriers' of it. It is interesting further to note that, up to the present, no case of furunculosis has been found among salmon smolts or among kelts, nor have any such fish been found to be 'carriers', but too few fish have as yet been examined to attach any but provisional value to this statement.

In the course of her investigations into furunculosis of Salmonidæ, the author has made additional general observations on bacterial infection in fish and certain

1 Fishery Board for Scotland. Salmon Fisheries, 1929, No. 1: Further Studies on Furunculosis of the Salmonidæ, 1928. By Isobel Office, 1929.) $6 d$. net.

No. 3146, VoL. 125] other lower vertebrates. ${ }^{2}$ It is found that organisms, naturally saprophytic, may under certain conditions become pathogenic. These organisms comprise types frequently found in water, such as $B$. fluorescens and certain Gram-negative, non-sporing, non-chromogenic bacilli.

Bacterial disease of fish and frogs usually takes the form of a general infection. Focal lesions may or may not be found. In furunculosis, infection may be both focal and general. Secondary infections, including ante-mortem infection, are of common occurrence in fish and frogs when the resistance of the animals has been lowered by primary infection, injury, and (possibly) other adverse conditions. Little or no tissue reaction against invading bacteria analogous to such reactions in mammalian animals has been found in frogs or fish, but a certain degree of phagocytic activity is displayed in some cases. "It seems certain", says the author, "that many water organisms are potentially pathogenic for fish, so that when they are injured or their resistance lowered by adverse conditions, these organisms invade their tissues and usually produce a general infection. Once bacteria have gained an entrance, they meet with but little opposition from the tissues and rapidly overrun the body."

2 Fishery Board for Scotland. Salmon Fisheries, 1929, No. 2: A Study of Bacterial Infection in Fish and certain other Lower Fish and Frogs in the course of investigation of Furunculosis of the Salmonidæ). By Ysobel J. F. Williamson. Pp. 28. (Edinburgh and London: H.M. Stationery Office, 1929.) 1s. 9d. net. 